\title{
THE SECOND CORPS OF ROMANIAN VOLUNTEERS IN RUSSIA
}

\section{Ioana Cazacu}

"Al. I. Cuza" University of Iassy, Faculty of History, E-mail:
ioanacazacu@yahoo.com

This paper has been presented at the First International Conference on Nordic and Baltic Studies in Romania: Romania and Lithuania in the Interwar International Relations: Bonds, Intersections and Encounters hosted by the Romanian Association for Baltic and Nordic Studies, Târgoviste, May 19-21, 2010.

\begin{abstract}
:
The situation of Romanian POWs has aggravated with the Bolshevik assuming of power. Following the Kiew occupation by Bolsheviks, the First Romanian Volunteers Corps has been disbanded and a great number of POWs remained on Russian territory with little possibilities to return to their native land. In these circumstances, the Romanians volunteers decided to depart for Moscow from where they hoped to leave for their country with the Romanian consul's support. However, the German authorities refused to allow their crossing through Ukraine and the volunteers had to cope with their staying in Russia. They set up a body of all officers in order to represent the Romanian cause both in Russia and in France: the Second Corps of Romanian Volunteers in Russia. This occasioned them to encounter other political-military forces acting in the Russian chaotic situation, a Lithuanian army corps included. The Romanians will continue their odyssey in their attempt to be evacuated through Vladivostok, they successfully fighting the Bolsheviks and finally returning to Romania. This paper elaborates over the fate of the Second Corps of Romanian Volunteers in Russia and their encounters with their Lithuanian, other Baltic and Czechoslovak fellows.
\end{abstract}

\section{Rezumat:}

Situația prizonierilor şi voluntarilor români rămaşi în Rusia s-a agravat o dată cu venirea bolşevicilor la conducerea statului. După ocuparea oraşului Kiev de către trupele bolşevice, Primul Corp al Voluntarilor Români a fost dizolvat şi un număr mare de prizonieri a rămas pe teritoriul Rusiei cu posibilități mici de întoarcere $\hat{\imath}$ țară. Pentru că misiunea română nu mai putea functiona voluntarii au primit o sumă de bani, apoi s-au îndreptat spre Moscova, de unde sperau să treacă în tară cu ajutorul consulului român. Autoritătile germane au refuzat, însă, permisul de trecere prin Ucraina şi românii s-au văzut nevoiți să se reorganizeze pe teritoriul rusesc. În urma consfătuirilor s-a hotărât ca românii să înființeze un organism 
puternic al tuturor ofițerilor, care să reprezinte cauza românească atât în Rusia cât şi în Franța. Astfel, a fost creat Al Doilea Corp al Voluntarilor Români. Situația de pe teritoriul rusesc era una confuză deoarece aici se afla un amalgam de forțe politico-militare, dintre care putem aminti Legiunea Cehoslovacă, Corpul Voluntarilor Români, un corp de lituanieni şi mai multe corpuri de estonieni. La finele primei conflagrații mondiale toate corpurile de voluntari trebuiau să se retragă de pe teritoriul rusesc. Trupele urmau să fie evacuate prin Vladivostok. În aceste conditiii, Legiunea Română a primit sarcina de a apăra Transsiberianul pe linia Zirna-Tulun-Nijin Udinsk-Bairanokov-Taişeț. Românii, în misiunea lor de a apăra linia de cale ferată, s-au confruntat cu trupele bolşevice, pe care le-au învins. Datorită comportamentului lor dur românii au primit de la localnici numele de "Dikaia Divizia" (Divizia Sălbatecă). Cu toate acestea, situația generală era una dificilă. În condițiile în care polonezii fuseseră decimați de bolşevică, dintre letoni au scăpat doar aproximativ 500, iar cehoslovacii refuzau să mai lupte în Siberia, trupele române au ajuns în ariergardă, unde asigurau retragerea trupelor cehoslovace. In iarna anului 1920, s-au intensificat luptele dintre armata roşie şi trupele de voluntari. Voluntarii români au respins în luptele de ariergardă armata bolşevică. Neputând invoinge trupele române, bolşevicii au cerut armistițiul. Conform acestuia bolşevicii se obligau să rămână $50 \mathrm{de} \mathrm{km.} \mathrm{în} \mathrm{urma} \mathrm{trupelor} \mathrm{de}$ ariergardă şi să înainteze spre răsărit doar in măsura posibilităților de retragere a Legiunii. Românii au rămas în ariergardă până la transferul complet al trupelor de voluntari în Transbaicalia.

Keywords: POWs, Russia, Romanian volunteers, Civil War, Bolsheviks

The Great War brought about an entirely new situation, generated by the existence of multinational empires, soldiers of the same ethnic origin being often part of the enemy camp. In this posture, among others, were also the Romanians living in the Austro-Hungarian Empire. Therefore, once Romania joined the Entente in the war, the Romanians from abroad wanted to join the Romanian army in the conflagration and so the corps of volunteers were created.

The new international context, starting with the early 1918, placed the prisoners and the Romanian volunteers from Russia in a critical situation. Besides, the Bolsheviks' coming to power and the outbreak of the civil war deteriorated the problem of the Romanians, who, after the occupation of Kiev by the Bolshevik troops, were forced to leave the city. It is important to note that in Darnita, near Kiev, a center for receiving Romanian prisoners from the Russian territory was organized in 1917. In this place, also, the First Romanian Volunteer Corps was established which aimed at sending contingents to fight on the Romanian territory against the Central Powers. To make the recruitment of volunteers easier, the Minister of War empowered Lt. C.G. Pietraru to organize the Service of Romanian 
Volunteers in Russia, Kiev, but the critical conditions in early 1918 caused the abolition of the Service. Moreover, the Romanian volunteers disguised as Russian soldiers moved to Chisinau and they passed in their country. In Darnita 10,117 volunteers, 396 officers and 9,971 soldiers were enrolled ${ }^{1}$.

Taking into account the above-mentioned events, the First Romanian Volunteer Corps was dissolved and most volunteers went to Moldavia. Even so, a large number of volunteers remained on Russian territory, having extremely limited opportunities to return to the country. In these conditions, each volunteer received 1,000 rubles in advance, the pay for two months and went to Irtkutsk. On their way to the established destination, the Romanians faced many difficulties, being arrested twice by the Bolshevik authorities as suspects, but released for lack of evidence. In addition, due to the proximity of the Central Powers' troops, the Romanian volunteers went to Moscow, hoping to receive assistance from the Romanian consul to enter their country. Nevertheless, the German authorities refused to let them pass through Ukraine and thus, the Romanian prisoners had to reorganize themselves ${ }^{2}$.

As a result of the conferences in Moscow, it was decided that the Romanian officers meet in Samara, on June 5, 1918, to set up a powerful organization of all officers to represent the Romanian cause, both in Russia and in France ${ }^{3}$. Due to the fights between the Czechoslovakian and Bolshevik troops, the Romanian officers could not meet on June 5. The Romanian meeting took place only on August 3, 1918, in Chelyabinsk, where a National Committee led by Voicu Nitescu organized the former prisoners and formed the first regiment, the Volunteer Corps from Chelyabinsk, named "Horia" 4

The conference decided to create the Second Corps of Volunteers from Transylvania, Banat and Bucovina, having as its main goal to continue the fight next to the Allies, against the Central Powers. During this conference, the Romanian National Committee was organized, as part of the Romanian military and political executive from Transylvania and

\footnotetext{
1 Marin C. Stănescu and Alexandru Roz, Prizonieri şi voluntari români din primul război mondial şi Marea Unire din 1918, [Romanian Prisoners and Volunteers of the World War I and The Great Union of 1918] (Arad: Vasile Goldiş University Press, 2003), 30-31.

2 Direcția Arhivele Naționale Istorice Centrale Iaşi, Folder Victor Cădere, file 2, 16-17. (Hereafter A.N.I. instead of naming the folder, to simplify the quotation, as we refer only to this archive folder, held in two locations: the Department of Central National Archives Iasi and the Central University Library, „Mihai Eminescu”, Iasi).

${ }^{3}$ Ibid., f. 19-20.

4 Ibid., file 1, 19.
} 
Bucovina. The president of the Committee was Nitescu, responsible for Foreign Affairs N. Nedelcu, responsible for finances Simion Gogan, military chief Valeriu Dimbu and secretary Corneliu Vaida ${ }^{5}$.

On August 24, 1918, the Romanian National Committee signed an act of collaboration and mutual support with the Czechoslovakian National Committee, according to which the Romanian part undertook to organize a Corps of Romanian Volunteers in order to fight for the liberation of the territories that were part of the Austro-Hungarian monarchy. In their turn, the Czechoslovaks obliged themselves to provide support for the Romanian volunteers in achieving the common goal, that of destroying the Austro-Hungarian Empire. In case the Corps of Romanian Volunteers didn't have enough officers, they were to appeal to the Czechoslovakian military department. The Czechoslovaks engaged to provide food, clothes and weapons and to take care of the auxiliary technical units. In addition, the Czechoslovaks had to cover all the expenses for propaganda and recruitment. The Romanian National Committee worked out the internal regulations, organized courts and schools of officers, proposed officers to be advanced to the Czechoslovakian National Committee, with the participation and permission of the Romanian National Committee, based on parity. In the end, it is precisely specified that the Second Corps of Romanian Volunteers be under the supreme guidance of the Romanian National Committee or another organism which represented the Romanian government ${ }^{6}$.

The prisoners answered promptly to the Call given on August 15, 1918 by the Romanian Committee. The number of the volunteers was of almost 5,000 people; a battalion was organized in Kurgan and five others in Petropavlovsk. The large number of volunteers caused problems to the leaders, who couldn't provide food, clothes and shelter for the new-comers. To solve this problem, Nitescu went to Ekaterinburg, the centre of the Czechoslovakian National Committee. The meeting of the two parts didn't solve the problems of the Romanians. The Czechoslovaks confronted the same problems: lack of money or shelter for volunteers 7 .

The initial plan which foresaw the embarking and sending of the volunteers on the French front was abandoned, the Allies wanted to remake the Oriental front and continue the hostilities against the Central

\footnotetext{
5 Ibid., file 2, 25.

6 Ibid., file 19, 7; Voicu Nițescu, Douăzeci de luni în Rusia şi Siberia (anul 1917) [20 Months in Russia and Siberia (1917)], vol. III (Braşov: Tipografia A. Mureşanu-Brănicescu, 1926), 125128.

7 Nițescu, 129-133.
} 
Powers8. To accomplish the plan, in Siberia were concentrated in 1918: 30,000 Japanese led by General Oi, 8,000 Americans led by General Graves, 50,000 Czechoslovaks, 3,000 Italians, 12,000 Poles, 3,000 Serbs, 12,000 Chinese, a corps of Lithuanians and more of Latvians9.

Internally, the corps of Romanian volunteers confronted difficulties caused by the lack of some well-trained and respected officers to impose themselves in front of them. This situation determined the Romanian National Committee to address the Czechoslovakian commandment, which, according to the convention signed on August 24, 1918, detached temporarily the Czech colonel Ed Kadlez to take care of the technical and military training of the Corps. The colonel received from the leaders the task to transport the Second Corps of Romanian Volunteers to Irkutsk, to complete their organization and military training. The mission was accomplished and, thus, at the end of 1918 the volunteers were already quartered in Irkutsk. Going east, the Romanians aimed at moving away from the fighting front with the Bolsheviks, disentangling the corps of the Russian internal fights and shortening the way to the free sea ${ }^{10}$.

Arriving in Irkutsk, the Romanian volunteers came into conflict with the Czech colonel Kadlez. In this context, General Janin, the chief of the French Military Mission and of the Allied Supreme Council, called for Nitescu to Omsk in order to explain the situation of the Romanian volunteers on the Siberian front. During the meeting, Nitescu emphasized the fact that the Romanian troops were going to interfere only in the areas where their interests coincided with those of the Allies. Moreover, at that moment, the main problem for Romanians was to repatriate all the contingents of volunteers. It is worthy to mention that, to accomplish their objective, the Romanian troops had to participate in guarding the Transsiberian, the only way to ensure the connection with the city of Vladivostok. Regarding the solving of the conflict between Romanians and Colonel Kadlez, General Janin put the Corps of Romanian Volunteers under the direct orders of the French Mission; a French officer was going to replace Colonel Kadlez ${ }^{11}$.

The relations between the Romanians and the Czech colonel worsened during Nitescu's leaving for Omsk. In the meantime, Kadlez had formed his general staff of Czech and Russian officers. Besides, he involved

\footnotetext{
8 Ibid., 143-144.

9 Victor Cădere, „Însemnările şefului de misiune," în Stări de spirit şi mentalități în timpul marelui război [The Notes of the Mission Chief, in Moods and Mentalities during the Great War)], eds. Ion Agrigoroaiei et al. (Iaşi: Editura Junimea, 2005), 141.

10 A.N.I., file 19, 8-9.

11 Ibid, 9-10.
} 
the Romanian troops in fights which weren't of interest for the Romanian volunteers. This turned into a memorial written by Voicu Nitescu and addressed to general Janin; this way the general was informed about the decision of the Romanians to change Colonel Kadlez. General Janin accepted the Romanians' request of replacing the colonel and he sent for the French officers Malgrat and Buinsse. However, the two officers didn't share the Romanians' ideas and sustained the activity of the Czech colonel, insisting that he remains to lead the Corps of Romanian Volunteers ${ }^{12}$.

The irreconcilable conflict between the Romanian volunteers, on the one side, and the Czech colonel and the French officers, on the other side, can be interpreted also as a conflict of interests. The Romanian National Committee had as objective obeying the orders coming from the country and avoiding any other confrontation that didn't serve the Romanian national interests. The interest of the Czech colonel Kadlez was to work his way up using the Romanian troops in the fight against the Bolsheviks. The French also wanted to use the Romanian volunteers in the fight against the red troops ${ }^{13}$.

The situation of the Romanian volunteers became very difficult when Nitescu went to the country in January 1919 to repatriate the volunteers and prisoners of Siberia. Colonel Kadlez treated offensively the members of the Romanian National Committee in many occasions and denounced them, accusing them of being on the Austrian side, on the Bolshevik side and of lacking discipline in relation to the Allied commandment. The accusations were formulated in front of Admiral Kolceak and the French general Janin. The conflict ended on February 19, with the order of recalling to the post of the Czech colonel. After a few days of conversations between Colonel Kadlez, Major Malgrat and General Janin, however, the order was called-off. Besides, on February 23, 1919, General Janin announced in a telegram that he suspended the Romanian National Committee from leading the corps of volunteers. The Corps of Romanian Volunteers was going to be transformed into a Legion Corps acting under the orders of the French Military Mission ${ }^{14}$.

The Corps of Romanian Volunteers was transformed, on January 26, 1919 in the Legion of Romanian Volunteers from Transylvania and Bucovina. Beside the three battalions: the first Battalion called "Horia", the second Battalion called "Marasesti" and the Reserve Battalion, two other companies of machine-gun were organized, a company of pioneers and a

\footnotetext{
12 Ibid., 10.

13 Ibid., file 2, 3-4.

14 Ibid., 5.
} 
school for grenadiers. In March the crisis was already over and on May 10 the Romanian government informed General Janin that it accepted that the Romanian Legion of Volunteers fights for the Ally cause, under the orders of the French Military Mission. Thus, the Romanian battalions received the mission of assuring the security of Transsiberian on the battle line Taiset, Zima, Tulum, Nijniudnsk, being the rearguard of the Czechoslovakian troops which wanted to retreat towards Vladivostok ${ }^{15}$. Among the 5,000 volunteers quartered in Irkutsk, only 2,000 wanted to be part of the newly formed legion. Some of them repatriated in small groups, others returned in camps as prisoners, not as volunteers. The Romanian Military Mission, led by Victor Cadere, repatriated them one year later ${ }^{16}$.

With this date begins the last stage of activity of the Romanian volunteers in Siberia. Next to the Romanian volunteers fought around 50,000 Czechoslovaks, a division of Japanese, around 10,000 Poles in Krasnoyarsk, 3,000 Serbs in Chelyabinsk, two battalions of Americans and a number of Lithuanians. This mixture of troops had the mission to defend and maintain the safety of Transsiberian and fight against the Bolshevik troops.

In 1919, the Romanian volunteers, in their mission of defending the railway line, confronted the Bolshevik troops which they defeated. Due to their harsh behaviour shown during the fights, the Romanians were called "Dikaia Divizia" ("The Wild Division"), name given by the local people17. But the situation became difficult, the conditions in which the Poles, the first who came into contact with the Bolshevik army, were ploughed down, while around 500 Latvians got away and the Czechoslovaks refused to fight in Siberia. This way, the Romanians had to fight in rearguard, where they ensured the retreat of the Czechoslovakian troops ${ }^{18}$.

In the winter of 1920, the fights between the Red Army and the troops of volunteers intensified. The Romanian volunteers succeeded in beating off the attack of the red troops in the rearguard fights. Being unable to defeat the Romanian troops, the Bolsheviks requested a truce, obliging themselves to keep a distance of $50 \mathrm{~km}$ behind the rearguard troops and go east only keeping in mind the Legion's retreating possibilities. In any case, the Romanians stayed in rearguard until the complete transfer of the

\footnotetext{
15 Ibid, file 19, 12.

16 Ibid., 9.

17 Stănescu and Roz, 208.

18 Elie Bufnea, Formațiile de voluntari, în Transilvania, Banat, Crişana, Maramureş 1918-1928, [Formations of Volunteers in Transylvania, Banat, Crisana, Maramurs, 1918-1928] (Bucureşti: Editura Cultura Civică, 1929), 129-130.
} 
volunteer troops in Transbaicalia19. In the end, on May 10, 1920, in Vladivostok, the Romanian volunteers were decorated with 68 foreign decorations (French, English, Italian and Czechoslovakian) for the courage they proved in the confrontation with the Bolsheviks ${ }^{20}$.

Thus, I consider that the activity of the Second Corps of Romanian Volunteers can be characterized as praiseworthy. Although they faced difficult moments caused by the Russian and Romanian armistices, the volunteer troops found possibilities to reunite and continue the fight for accomplishing the national ideal, next to the other Allied troops. Anyone's sacrifice in Russia cannot be forgotten and that is why it is important to remember the activity that the Romanian volunteers, next to their fellowsoldiers of other nationalities, carried on Siberian territory. The difficulties met in accomplishing the proposed goal had many causes such as, first, the Romanians' refusal to interfere in the internal Russian problems, but also their desire to fight only to support the Romanian cause. Through the successes against the Red Army, the Romanian volunteers gained the respect of the other missions, providing determination and courage appreciated by their both allies and enemies.

\section{References:}

\section{A. Archives:}

Direcția Arhivele Naționale Istorice Centrale Iaşi [Department of Central National Archives Iasi]: Folder Victor Cădere, files 1, 2, 19

\section{B. Diaries, memoirs:}

Cădere, Victor. „Însemnările şefului de misiune.” In Stări de spirit şi mentalități în timpul marelui război [The Notes of the Mission Chief, in Moods and Mentalities during the Great War)], eds. Ion Agrigoroaiei et al. Iaşi: Editura Junimea, 2005.

Nițescu, Voicu. Douăzeci de luni în Rusia şi Siberia (anul 1917) 20 Months in Russia and Siberia (1917)]. vol. III. Braşov: Tipografia A. Mureşanu-Brănicescu, 1926.

\section{Books and articles:}

Bufnea, Elie. Formațiile de voluntari, în Transilvania, Banat, Crişana, Maramureş 19181928, [Formations of Volunteers in Transylvania, Banat, Crisana, Maramurs, 1918-1928]. Bucureşti: Editura Cultura Civică, 1929.

Stănescu Marin C., and Alexandru Roz. Prizonieri şi voluntari români din primul război mondial şi Marea Unire din 1918, [Romanian Prisoners and Volunteers of the World War I and The Great Union of 1918]. Arad: Vasile Goldiş University Press, 2003.

19 Ibid., 130.

20 A.N.I., file 19, 19. 